\title{
Notions of Home: Re-Locations and Forging Connections in Paule Marshall's Brown Girl, Brownstones
}

\author{
Ashma Shamail \\ Department of English Language \& Literature \\ College of Science and Humanities, Jubail \\ Imam Abdulrahman Bin Faisal University, Dammam, Kingdom of Saudi Arabia
}

\begin{abstract}
Focusing on the African Caribbean Immigrants in the United States, this paper examines the work of novelist Paule Marshall, whose narratives document issues of migration, displacement, home, return, and community bonding. Paule Marshall's first novel Brown Girl, Brownstones (1959), focuses on Selina Boyce, a second-generation Barbadian immigrant from the United States, whose search for her roots is informed by an inherent link to the Caribbean through an articulation of the dynamics of belonging. The notion of 'home' as a contradictory and contested trope is vital, for the writer's foremost concern is on the overarching effect it has on the diasporic subject. Marshall grants her protagonist the space to challenge familial struggles, and reclaim her voice by relocating to Barbados, her parental home. The protagonist's enigmatic journey through ambivalent interspaces enables her to reconstruct bridges to the West Indies. Marshall's examination of her young protagonist's 'return to the Caribbean' reflects wider issues of diasporic identity and belonging connected to 'home' spaces, ancestral lands, regions, and origins.
\end{abstract}

Keywords: Afro-Caribbean immigrants, Barbados, belonging, diasporic identity, home

Cites as: Shamail, A. (2018). Notions of Home: Re-Locations and Forging Connections in Paule Marshall's Brown Girl, Brownstones. Arab World English Journal for Translation \& Literary Studies, 2 (4). 71- 88. DOI: http://dx.doi.org/10.24093/awejtls/vol2no4.5 